\title{
CAN COLLABORATIVE LEADERSHIP BE A SOUL FOR DEVELOPMENT OF SUSTAINABLE TOURISM? : STUDY IN KARANGANYAR DISTRICT
}

\author{
Jacika Pifi Nugraheni, Sudarmo, and Rutiana Dwi Wahyunengseh \\ Post Graduate Student in Public Administration; Faculty of Social and Political Science, \\ Universitas Sebelas Maret \\ Jacika.cikapiff94@student.uns.ac.id, Sudarmo@staff.uns.ac.id, Rutiana@staff.uns.ac.id
}

\begin{abstract}
Tourism development is believed to be able to improve the economy of local communities, even tourism development is one strategy in reducing poverty, especially in rural communities. But in Indonesia rapid tourism development has the potential to isolate the economy of local communities. This occurs because the tourism business is managed on a large scale by the private sector. Various studies support that this weakness occurs because there is no maximum empowerment of local communities in managing it, so that the community loses control of tourism development. This study aims to interrogate how collaborative leadership is carried out to support sustainable tourism development and how collaborative leadership should be carried out as an effort to effectively increase tourism's contribution to the local economy. To analyze this, this study uses four collaborative leadership variables namely embracing, empowering, involving and mobilizing. The method used is literature study and interview. Research locus in Karanganyar Regency. The results of the analysis show that there is no maximum empowerment of local communities in developing sustainable tourism because of there are obstacles in implementing collaboration are from the agenda of screening and integration of political aspects. This research also suggests that in order to achieve sustainable tourism development it is necessary to develop institutions in the embracing process in the collaborative leadership agenda as well as cooperation between regions. Thus, this paper can contribute theoretically in linking between collaborative leadership models and institutional development for effective sustainable tourism development.
\end{abstract}

Key Word : collaborative;community empowerment; institutional; leadership; tourism

\section{Introduction}

Tourism activities in its development have started to be highlighted as one of the different economic improvement strategies from the economic improvement program in general, this is because the tourism sector has a strong defense under any conditions proven by data when the global crisis occurs several times, the number of international tourist trips remains show positive growth (Briedenhann \& Wickens, 2004; Sutawa, 2012; UN-WTO Tourism Highlight 2014, UN-WTO World Tourism Barometer 2015, WTTC 2015).

Based on the RPJMN (2015-2019), it was explained that through the 2010 GDP calculation, the tourism industry in Indonesia became a priority policy which was activated as one of the domestic economic strategies to create a more independent economy. The tourism industry has proven to be able to stimulate competitiveness against the acceleration of the country's economic growth.

This is supported by World Economy Forum (WEF) data which shows a significant increase in Indonesia's tourism competitiveness, which is ranked 42nd with a value of 4.16 in 2017 from 141 countries in the world (LAKIP Kemenpar in 2017). In 
addition, LAKIP Kemenpar (2007) also provides information that the contribution of tourism in Indonesia can be seen from the amount of foreign exchange receipts of 205.04 trillion rupiah from the initial target of 182 trillion rupiah in 2017 and employment of 12 million people.

Various previous studies have found that tourism development potential not only contributes greatly to national economic growth, but also is able as a strategy to alleviate poverty, especially in rural areas (Luvanga \& Joseph, 2003; Gao, Huang \& Huang; 2009; Truong, Hall, \& Garry, 2014).

As in Sapa, Vietnam, rural communities are more of the opinion that tourism plays a role in alleviating poverty (Truong, Hall, \& Garry, 2014). In addition, the results of research in rural Tanzania, namely Mto wa Mbu Barabani and Kilimamoja also found that tourism has a positive impact on reducing rural poverty because the tourism industry is able to create direct and indirect employment for rural communities, especially in terms of cultural tourism because it does not requires special expertise (Luvanga \& Jospeh, 2003).

Although tourism development is considered capable of improving the welfare of local communities, especially rural areas, there are not a few phenomena of tourism development in Indonesia that have not significantly provided economic benefits to rural communities and have the potential to isolate local communities (Damanik, 2005; Dewi, Fandeli \& Baiquni, 2013).

Concerning conditions also occur because tourism development handed over to foreign parties actually strengthens capitalism in the tourism industry. This occurs in some of the leading destinations in Indonesia, such as Wakatobi, Karimun Jawa, Anambas, Pulau Cubadak, and Raja Ampat (https://www.kaskus.co.id). This phenomenon has shown tourism development through strong control from the government and based on the growth paradigm, this has changed the role of the government which should act as a facilitator to become a single player in tourism development (Damanik, 2005; Dewi, Fandeli \& Baiquni, 2013). The direct implication of local community participation is not accommodated so that tourism development in the region cannot improve the welfare of local communities (Briedenhann \& Wickens 2004; Briedenhan \& Pranill, 2005; Schieyvens \& Russell, 2012).

Previous research has discussed a lot that the key to success in tourism development is empowering local communities (Sutawa, 2012; Boley., et al, 2014). This research draws further the instruments needed to carry out empowerment itself. Empowerment from the local community for this purpose requires a bridge of change that starts from "planning" through a participatory approach that will facilitate the application of the principles of sustainable tourism development and create better opportunities for local communities to get greater and more balanced benefits from tourism development that takes place in their area, and produces more positive attitudes from tourism development and the conservation of local resources (Tosun, 2000; Tosun, 2006; Sutawa, 2012). To realize a bridge of change, the main determining factor is leadership. Leadership in question is leadership that has the ability to facilitate 
empowerment (Rosenthal, 1998; Mullen \& Kochan, 2000; Briedenhann \& Pranill, 2005; Sutawa, 2012).

This study uses collaborative leadership analysis. Collaborative leadership analysis is considered most suitable by researchers to analyze tourism problems because in this collaborative leadership model requires management of government structures, administration, organizational autonomy processes, mutualism and norms by empowering, encouraging broad participation in decision making, and fostering accountability, in accordance with the basis of sustainable tourism development (law number 10 of 2009; RI Government Regulation Number 50 of 2011; Raelin, 2006; Thomson \& Perry, 2006; Anshel \& Gash, 2007; Hallinger \& Heck, 2010).

This is manifested in four collaborative leadership variables namely embracing, empowering, involving and mobilizing (Vangen \& Huxam, 2003; Raelin, 2006; Anshel \& Gash, 2007; Hallinger \& Heck, 2010).

This study took a locus in Karanganyar Regency. Karanganyar Regency is one of the districts in Central Java, the geographical location of Karanganyar Regency, which is located on the slopes of Mount Lawu, makes this area has a lot of natural tourism potential compared to other regions (Eskamurti, 2016). Thus, tourism policy is a priority of the Karanganyar Regency regional government. Supported by giving other names in this area, namely the Earth "Intanpari" which stands for Industry, Agriculture and Tourism.

Thus, this study aims to further analyze how collaborative leadership is carried out to support sustainable tourism development, especially in Karanganyar Regency and how collaborative leadership should be carried out as an effort to increase tourism's contribution to the local economy effectively.

\section{Collaborative Leadership}

Raelin (2006) explained that the main characteristic of collaborative leadership is always based on humanistic principles. This fundamental humanistic form is realized by providing opportunities for all members to participate in efforts to achieve common goals, both in the planning process and in their implementation.

Collaborative leadership changes the view that organizational success is not in one individual, but the success of the organization can be achieved through leadership that is able to work with parties both within the organization and outside organizations involved in a change (Vangen \& Huxam, 2003; Raelin, 2006; Jameson, 2007; Botha \& Triega, 2014).

To be able to carry out collaborative leadership, leaders need changes in orientation and skills. Jameson (2007) explaining collaborative leadership requires the power to share authority, knowledge and responsibility, not just centered on the authority of the hierarchy and the authority possessed. In addition, collaborative leadership must be able to maintain a balance between the need to build trust, manage power relations, ease communication, handle differences in interests between members or interpersonal trust, control, continuity and change, and formal procedures (Mullen \& Kochan, 2000; Alexander., et al, 2001; Raelin, 2006). 
In this collaboration theory, it means applying leadership that can affect the whole organization and not just individuals, but it also applies leadership that has the responsibility and expertise needed not because they have the mantle of authority. Some important aspects that are taken into consideration in implementing leadership collaboration are the media or the environment; capacity; structure; process and participants (Fawcett., et al, 1995; Vangen \& Huxam, 2003; Raelin, 2006).

Basically, this collaborative leadership includes activities that "facilitate", namely activities such as allowing all members to have a voice and seek consensus or agreement regarding the establishment of a collaborative agenda (Vangen \& Huxam, 2003; Anshel \& Gash, 2007).

The four activities are the basis of a collaborative leadership spirit, among others: 1) embracing, embracing everyone needed, the challenge is when there are some people who are reluctant to be embraced; 2) empowering, that is, activities in situations where members are not fully within the organization, but keep communication flowing effectively at any time to members directly, professionally and provide special assistance to individuals when there are members who need support; 3) involving, activities carried out to activate member participation, involving all members even though they have unequal roles and positions of power in collaboration. Maintain commitment for all members; 4) mobilizing, activity of moving members to make things happen, the example of the challenge Encouraging members to work in the name of collaboration is that they need something in return (Vangen \& Huxam, 2003; Botha \& Triega, 2014).

Vangen \& Huxam (2003) explain the challenges in the collaborative leadership process, which must be able to do :

A. Collaboration agenda: (a) mobilize, introduce and explain to members about an understanding of the substantive issues of what is the focus of collaboration; (b) influence the collaboration agenda through silent behavior and allow active members; (c) giving direction to its members how to move the agenda forward; (d) give authority to members to deal with problems that are collaborative studies.

B. Political aspects: (a) understanding the interests of the parties involved in collaboration; (b) have information about the parties involved, who influences who, knows the parties that are pro and contra, ensures that collaboration is carried out with pro parties, establishes intimacy, and develops collaboration; (c) not everyone wants to work together, the leader must manage the relationship between the parties involved in order to avoid conflict; (d) in the collaborative process, the leader continues to sort out who is the pro and pushes the counter parties to leave. 
Figure 1 Model of Collaborative Leadership

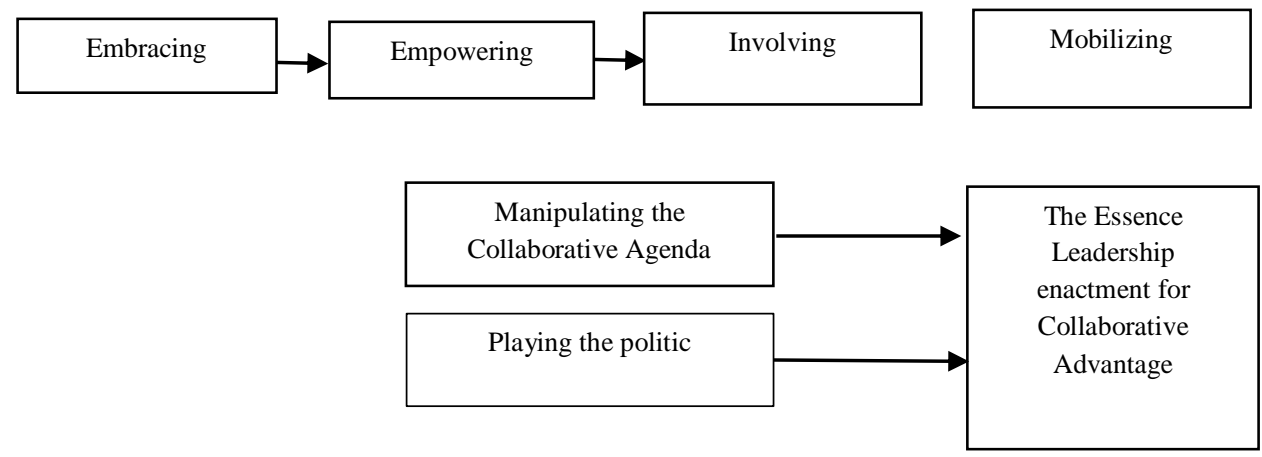

(Source : Vangen \& Huxam, 2003, p. 74).

\section{Research Method}

This study aims to analyze how collaborative leadership is carried out to support sustainable tourism development and provide recommendations on how collaborative leadership is carried out.

We use qualitative method which has consequence of the researcher is a key instrument (Sugiyono, 2003).

Unit of analysis of this study is the Karanganyar Regency Tourism and Youth Office, and the business community in Karanganyar Regency. The location samples taken came from 2 regions in Karanganyar Regency, including Ngargoyoso District and Jenawi District. The selection of these two regions is because this region has many potential natural attractions, including tea plantations, waterfalls and historical relics, namely the temple.

Specifically the participant of the business participant 1 , the management of PHRI (Association of Indonesian Hotels and Restaurants) in the Kemarging area of Ngargoyoso; participant 2 members of the semulur community of the Ngargoyoso District; participant 3, member of the Ngargoyoso District TPID team; participant 4, member of PHRI Jenawi District; participant 5, employee in the development of destinations for the Karanganyar Regency Tourism, Youth and Sports Agency; participant 6, socio-entrepreneurial practitioner in tourism.

This study involve various data sources including interviews to get an overview of the implementation of collaborative leadership and literature review to better understand institutional development opportunities in collaborative leadership.

The pattern of analysis in this study is (1) collecting information relating to the implementation of the collaborative leadership agenda namely embracing, empowering, involving and mobilizing; (2) from the information gathered the description of the interaction is explained; (3) draw conclusions; (4) provide an argument based on the liteature review on institutional development in the process of implementing collaborative leadership effectively. 


\section{Findings And Arguments}

The results of the investigation found that the local government has not embrace the community and other parties who could contribute to tourism development. As evidenced by the history of tourist attractions, especially the Kemuning tea plantation, which is located in Ngargoyoso District, it is strategic location was initially only a supporting village for tourist destinations in Ngargoyoso District.

The advantages that have a beautiful view, can attract many tourists. This potential is not welcomed by the government to maximize economic benefits for local communities. Until now, the people there who have already started a business trading small shops and lodging places or those who have not, did not get direction from the authorities to develop the tourism area. Since long ago the community formed the community according to its type of business independently. They run their business without capital assistance or direction from the government.

Information from business people in Jenawi District also stated the same thing "in my place is not from the government, so we have a hospitality association in this area, the Jenawi area is called region 2. Region 1 is Tawangmangu. Every once a month, we hold a meeting, we meet to discuss everything that we want to develop. We also hold social gathering to keep the spirit of the members. But for tourism offices, in this case the authorities have so far not provided any information or assistance in any case at all, so for example if we are going to make a boarding board for the location of the inn, we will make it ourselves. Then for IT problems, our business marketing tries to learn on its own" (Participant 4, personal interview, October 31, 2018).

The Tourism Office claims that the program carried out is related to inviting the public, it is socialization to business people in the field of tourism services. The socialization was carried out in accordance with the requirements and articles of association that had been previously determined. The socialization was carried out related to the dissemination of business licenses and insurance. But in the case of sustainable tourism development it is not enough to just carry out such information. The socio-enterpreneur practitioners in the tourism sector explained that forming a tourism design for community empowerment that should be carried out by the regional government was more emphasis on the aspect of human resources. The role of the community must be developed and facilitated by the local government, namely: as a source of customs, traditions, culture, as a good host for tourists and tourism development actors in accordance with their capabilities, and tankers (anti-violence team) where the community has an obligation to maintain security and order around attractions and secure tourists from crime (Participant 6, personal interview, September $15,2018)$.

This shows that leadership in terms of tourism development does not have the ability to embrace all parties that should be related to work together to develop tourism. The Ministry of Tourism explained the participatory tourism development formula known as the ABCGM "penthahelix model". At least there are five elements 
that must be embraced, namely academics as drafter, business or private sector, community and Society as accelerator, government as regulator, media as catalyst.

This weakness is also caused by the Karanganyar Regency Tourism, Youth and Sports Office as the most responsible party having a small structure and a lack of competent field staff to go directly to the community. The researchers found that they were preoccupied with administrative matters rather than approaching the community.

Furthermore, it was also found that to date decision-making for tourism development has not involved local communities. Planning is done in a top down manner, it is from the government as a determinant. In addition, so far the activities carried out by the regional government are more on marketing tourism objects, such as documentation of traditional ceremonies and create catalog (Participant 5, personal interview, September 30, 2018).

These findings reinforce the results of the interrogation of the people who claimed that there had not been any empowerment carried out to build these tourist attractions into tourist destinations together with the participatory principle.

In 2017, the Regional Government made a policy of building a 70-meter glass bridge (Kemuning Glass Sky Bridge) with a height of 30 meters. The Regional Government cooperates with the private sector as investors, namely PT De Kemuning. The value of the investment given is 55 billion. The tourism business which will be managed by PT De Kemuning is related to the construction of a glass bridge, gate or entrance ticket, lodging or hotel, restaurant, souvenir shop, traditional store, and parking.

Now community of traders in the Kemuning village is precisely on the construction site of a glass bridge project of 27 residents. In the community all of them provide instant food and drinks, there are also those who provide public bathroom services. They currently still occupy the traditional store they built independently. However, if the traditional store established by PT De Kemuning has been completed, they will be moved to the stalls. The traditional store were 32 rooms, 27 were planned to move residents who had already sold, 2 rooms for toilets, and the rest for local officials. Other conditions to be able to occupy the traditional store that was established, residents who sell must pay a number of contract fees or traditional store rental (Participant 1 \& 2, personal interview, September 23, 2018).

Regarding the development, the community has participated in them. People only get information that they will build glass in their area. In addition, member of TPID also explain "the real role of the Disparpora if it does not yet exist, for UMKM, agrotourism established by community. For BUMdes, the budget is partly from APBdes (participant 3, personal interview, November 3, 2018).

The explanation from the participants illustrates that until now there has been no direction or tourism development from related agencies. Especially, For the development of the Berjo BUMdes in Ngargoyoso District, they are under the direction of the Village Community Empowerment Service Office of the Karanganyar Regency. 
This shows that leadership is not capable of empowering. Empowering in this case also means the form of a community to create a community or community that is responsive in understanding its capabilities, with the aim of effectively meeting the needs of groups and the wider community, providing assistance to members and environmental control including their accessibility to related resources with work, social activities, and others (Perkins \& Zimmerman, 1995; Totok \& Purwoko, 2012).

Apart from the lack of ability to embrace and empower, the results of the study also found that they could not involve the community as the main actors in tourism development. In tourism development planning community access is very closed to intervening in their policies.

Existing leadership is not able to through structural boundaries to make changes, it will be difficult to achieve participatory tourism development (Rosenthal, 1988; Mullen \& Kochan, 2000; Alexander., et al, 2001; Vangen \& Huxam, 2003; Raelin, 2006; Anshel \& Gash, 2007).

After more in-depth research, it was found that there was an internal conflict in the related department. Conflict is very prominent in the field of development of promotion destinations and sub-fields. Conflict occurs between leaders in one organization. It also becomes an obstacle to internal communication which has an impact on the output of their activities in the community.

Existing leadership can not be called collaborative leadership, in addition to the absence of the ability to embrace, empower, involves also mobilizing. No participatory activities were mobilized. Especially in the field of tourism development, leadership is required to be able to become collaborative leadership not only embrace, empower, involve and mobilize internal members but also embrace, empower, involve and mobilize other parties from outside the organization or agency. In accordance with what is explained in Law Number 10 of 2009 that tourism development cannot be carried out unilaterally by the government but must involve local communities as stakeholders who understand the values and culture of the local area in order to achieve successful sustainable tourism development, namely increasing tourism contribution towards the welfare of the local community.

The results of the study also show that the local government concerned has a political choice in tourism development which is quite difficult. The tendency of local governments rather than empowering, selling tourism objects that have the potential to become tourist destinations for the private sector is an institutionalized thing. As in the cases that occur in other tourism development, that the government is incapable when faced with political choices, and tends to prioritize results that is profit rather than process (Briedenham \& Wickens, 2004; Chi-Ok oh, 2005; Butcher, 2005).

As explained earlier, if more investors enter an area to build tourism, economic growth will be faster because they have large capital, they tend to control assets and monopolize various businesses providing tourism needs.

Some previous studies have found that this condition also occurs because the factors of the community environment, namely the lack of competent human resource 
capacity results in the inability of local communities to provide safety infrastructure which is considered important in considering tourist visits. Thus, cooperation with the private sector will be more profitable (Briedenhann \& Wickens, 2004; Chi-Ok Oh, 2005; Duim., et al, 2005). On the other hand empowerment carried out from "zero" to the community will run takes a long time.

Institutional Development in Collaborative Leadership

From the results of the research, we invite readers to look at the whole about collaborative leadership as an important component in the sustainability of tourism. We adopted a spider model to analyze this form of leadership. Collaborative leadership can be translated into the ability to carry out a larger coalition such as a spider network in this context is to develop its institutions (Mullen, 2000; Jameson, 2007).

The leadership that creates a coalition (connects individuals across institutions) and all of its attributes as spider models, creates and re-creates networks and members in them, they bring individual strength into group strength through the distribution of authority. The network was expanded into something beautiful, in constant motion like a spider spinning in a new dimension and expanding connections (Mullen, 2000; Botha \& Triega, 2014).

The node part as a link is formed from the initial motivation of individuals joining, among others, to fulfill individual goals, strengthen individuals and organizations, benefit from other personal advantages and desire to create different roles (Mullen, 2000, p. 196). Furthermore, the unity will help each individual part become synergistic.

The important thing that cannot be ignored is the application of humanistic principles or their hearts and souls (Mullen, 2000; Raelin, 2006). The humanistic principle is the basic sense of "who we are, what we care about, and what we believe in" (Mullen, 2000, p. 194). This principle is the foundation of the synergy between members. Mullen (2000) explaine that synergi which showing that there is an energy of refreshing enthusiasm from the coalition to be a driving force in creating feelings of empowerment among members.

Likewise in tourism development, there are three main activities, namely the development of destinations, facilities and marketing. This will be effective if it is carried out across sectors, especially the area that is the location of this study adjacent to other areas. For example, in terms of accessibility of tourists from the airport to tourist destinations in Karanganyar Regency, tourists will pass through several areas before reaching the destination. This is a good potential if they support each other. Collaborative leadership that applies the spider model will continue to embrace and expand its network even across sectors.

\section{Conclusion}

We can draw conclusions on the conditions of collaborative leadership in this study. Participatory tourism development has not yet been implemented, this is due to 
the inability of collaborative leadership to implement their collaborative agenda and the influence of political aspects. This is indicated by a planning process that uses a top down approach, unable to capture coalitions with internal members and the community. In addition, a small and rigid organizational structure makes leaders unable to penetrate structural boundaries to make synergy with other parties well.

Next, we provide advice, not only for our research location, but for sustainable tourism development in various regions. They must apply collaborative leadership that is able to create networks (spider models) widely to achieve effective sustainable tourism development. The initial step taken was to embrace not only the internal parties of existing organizations and the community but also various other stakeholders described in the ABCGM penthahelix model and embrace other networks as well as inter-regional cooperation. This can be called institutional development.

\section{Acknowledgment}

We thank the Berjo Village Innovation Program Team, the Ngargoyoso and Jenawi Community, the Karanganyar Regency Tourism, Youth and Sports Service and our colleagues from the social-entrepreneurship practitioners from Temanggung who provided very helpful research insights, even though they may not agree with all interpretation / conclusion of this paper.

\section{References}

Alexander, J. A., et al. (2001). Leadership in Collaborative Community Healtd Partnership. Nonprofit Management \& Leadership, 12(22):159-175.

Ansell, C., \& Gash, A. (2007).Collaborative governance in Theory and Practice. Journal of Public Administration Research and Theory. 18: 543-571.

Boley, BN., et al. (2014). Empowerment and Resident Attitudes Toward Tourism: Strengthening The Theoretical Foundation Through A Weberian Lens. Annals of Tourism Research, 49: 33-50.

Botha, R. J., \& Triega, P. K. (2014). Distributed Leadership Towards, School Improvement: Case Study in South African Schools. International Journal of Educational Sciences, 7(2): 309-317.

Briedenhan, J., \& Pranil, R. (2005). Township Tourism: Blessing or Blight? The Case of Soweto in South Africa. Cultural Tourism in a Changing World Politics, Participation and (Re)presentation, 1(8): 124-142.

Briedenhann, J., \& Wickens, E. (2004). Tourism Routes as A Tool For The Economic Development of Rural Areas: Vibrant Hope or Impossible Dream?. Tourism Management, 2(5): 71-79. 
Butcher, J. (2005). Cultural Politics, Cultural Policy, and Cultural Tourism. Cultural Tourism in a Changing World Politics, Participation and (Re)presentation, 1(2): 21-35.

Chi-Ok Oh. (2005).The Contribution Of Tourism Development To Economic Growth In The Korean Economy. Tourism Management, 26: 39-44.

Damanik, J. (2005). Kebijakan Publik dan Praksis "Democratic Governance" di Sektor Pariwisata. Jurnal Ilmu Sosial dan Ilmu Politik, 8(3): 331-350.

Dewi, M. H. U., Fandeli, C., \& Baiquni, M. (2013). Pengembangan Desa Wisata Berbasis Partisipasi Masyarakat Lokal di Desa Wisata Jatiluwih Tabanan, Bali. Kawistara, 3(2): 117-226.

Duim, R.V.D., et al. (2005). Cultural Tourism in African Communities : A comparison between cultural Manyattas in Kenya and the Cultural Tourism Project in Tanzania. Cultural Tourism in a Changing World Politics, Participation and (Re)presentatio, 1(7): 104-123.

Eskamurti, E. (2016). Pengaruh Implementasi Kebijakan Pariwisata terhadap Kesejahteraan Masyarakat (Studi pada Masyarakat Sekitar Objek Wisata Alam Air Terjun Jumog di Desa Berjo Kabupaten Karanganyar). Universitas Sebelas Maret, Surakarta.

Fawcett, S.B., et al. (1995). Using Empowerment Theory in Collaborative Partnership for Community Health and Development. American Journal of Community Psychology, 23(5): 671-697.

Gao, S., Huang, S., \& Huang, Y. (2009). Rural Tourism Development in China. International Journal of Tourism Research, 11(5): 439-450.

Hallinger, P., \& Heck, R.H. (2010). Collaborative Leadership and School Improvement: Understanding the Impact on School Capacity and Student Learning. School Leadership E Management, 20(2): 95-110.

Jameson, J. (2007). Investigating Collaborative Leadership for Communities of Practice in Learning and Skills, Research Report.

Kaskus (2014, October 25). Lima Objek Wisata di Indonesia yang Dikuasai Asing. https://www.kaskus.co.id.

Laporan Akuntabilitas Kinerja Kementerian Pariwisata (LAKIP) Tahun 2017

Law RI Number 10 of 2009 about Tourism

Luvanga, N \& Joseph, S. (2003). The Role of Tourism in Poverty Alleviation in Tanzania. Nyota Publisher: Tanzania. 
Mullen, C.A., \& Kochan, F.K. (2000). Creating a Collaborative Leadership Network, an Organic View of Change. International Journal of Leadership in Education, 3(3), 183200.

Participant 1 (2018, September 23). Personal Interview

Participant 2 (2018, September 23). Personal Interview

Participant 3 (2018, November 3). Personal Interview

Participant 4 (2018, October 31). Personal Interview

Participant 5 (2018, September 30). Personal Interview

Participant 6 (2018, September 15). Personal Interview

Perkins, D. D., \& Zimmerman, M.A. (1995). Empowerment Theory, Research, and Application. American Journal of Community Psychologi. 23(5):569- 579 .

Raelin, J. (2006). Does Action Learning Promote Collaborative Leadership?. Academy of Management Learning E Education, 5(2): 152-168.

RI Government Regulation Number 50 of 2011

Rosenthal, C.S. (1998). Determinants of Collaborative Leadership: Civic Engagement, Gender or Organizational Norm. Political Reseacrh Quartely, 52(4): 847-868.

Schieveyns, R., \& Russel, M. (2012). Tourism, Land Tenure and Poverty Alleviation in Fiji. Tourism Geographies, 14(1): 1-25.

Sugiyono.2003. Metode Penelitian Bisnis. Bandung: Pusat Bahasa Depdiknas.

Sutawa, Gusti Kade. (2012). Issues on Bali Tourism Development and Community: Empowerment to Support Sustainable Tourism Development. Procedia: Economic and Finance, 4(1): 413-422.

Thomson, A. M., \& Perry, J.L. (2006). Collaboration Process: Inside the Black Box. Public Administration Review, 66: 20-32.

Tosun, C. (2000). Limits To Community Participation In The Tourism Development Process In Developing Countries. Tourism Management. 21:613-633.

Tosun, C. (2006). Expected Nature Of Community Participation In Tourism Development. Tourism Management, 27: 493-504.

Totok dan Poerwoko. (2012). Pemberdayaan Masyarakat Dalam Prespektif Kebijakan Publik. Alfabeta: Bandung. 
Truong, V.D., Hall, C, M., \& Garry, T. (2014). Tourism and Poverty Alleviation: Perceptions and Experiences of Poor People in Sapa, Vietnam. Journal of Sustainable Tourism, 22(7): 1071-1089.

UN-WTO Tourism Highlight 2014. https:// www.e-unwto.org

UN-WTO World Tourism Barometer 2015. http://tourlib.net/wto/2015

Vangen, S., \& Huxham, C . (2003). Enacting Leadership for Collaborative Advantage: Dilemmas of Ideology and Pragmatism in the Activities of Partnership Managers. British Journal of Management, 14; 61-76.

World Travel Tourism Council (WTTC) 2015. https://zh.wttc.org/Lmedia/files/reports/economic-impact-research-2015/ 